\title{
An Unusual Case of Cushing's Syndrome: Coexistence of Functional Pituitary and Adrenal Adenoma
}

\author{
Nadir Bir Cushing Sendromu Olgusu: Fonksiyonel Hipofiz ve Adrenal Adenom \\ Birlikteliği
}

\author{
Muzaffer IIlhan, Özcan Karaman*, İrem Yasin Çetin**, Nur Büyükpınarbaşılı***, \\ Jamshid Hamdard**, Ertuğrul Taşan* \\ Ümraniye Training and Research Hospital, Clinic of Endocrinology and Metabolism Diseases, Istanbul, Turkey \\ *Bezmialem Vakif University Faculty of Medicine, Department of Endocrinology and Metabolism Diseases, istanbul, Turkey \\ **Bezmialem Vakıf University Faculty of Medicine, Department of Internal Diseases, Istanbul, Turkey \\ ***Bezmialem Vakıf University Faculty of Medicine, Department of Pathology, Istanbul, Turkey
}

\section{Abstract}

A case of adrenocorticotropic hormone (ACTH)-independent Cushing's syndrome, which develops in the course of ACTH-dependent Cushing's disease, is presented in this report. A 47-year-old woman with a past history of surgery and gamma knife radiosurgery because of Cushing's disease was admitted to the endocrinology clinic with weight gain and unregulated blood glucose levels. Hypercortisolemia was still persisting and diagnostic work-up indicated ACTH-independent Cushing's syndrome. Along with the rare possibility of this coexistence, longstanding ACTH hypersecretion can play a role in functional transition of adrenal adenomas. Further studies are needed to clarify the underlying mechanisms.

Keywords: Cushing's syndrome, Cushing's disease, adrenal adenoma
Bu olgu sunumunda aynı hastada adrenokortikotropik hormon (ACTH) bağımlı Cushing hastalığı seyrinde gelişen ACTH bağımsız Cushing sendromu sunulacaktır. Cushing hastalığı sebebiyle cerrahi ve gamma knife uygulanmış olan 47 yaşındaki hasta endokrinoloji kliniğine kilo alma ve regüle olmayan kan şekeri sebebiyle başvurmuştur. Yapılan tetkikler hiperkortizolemisinin bulunduğunu ve hiperkortizoleminin ACTH bağımsız hale geldiğini göstermiştir. Bu ko-insidansın çok nadir bir olasilık olmasıly beraber, uzun dönem ACTH hipersekresyonu daha önceden fonksiyonel olmayan adrenal adenomun fonksiyonel hale gelmesinde rol oynamış olabilir. Bu konuda altta yatan mekanizmaların aydınlatılması için ileri araştırmalara ihtiyaç bulunmaktadır.

Anahtar Sözcükler: Cushing sendromu, Cushing hastalığı, adrenal adenom

\section{Introduction}

Cushing's syndrome (CS) is a disorder that results from pathological exposure to excess glucocorticoids (1). Endogenous CS is a rare entity with an incidence of 2-4 cases per million per year $(2,3)$. Approximately $80-85 \%$ of cases result from adrenocorticotropic hormone (ACTH)dependent causes and an accurate endocrine evaluation is mandatory in every steps of CS diagnosis $(4,5)$. In this report, we present a case of ACTH-independent CS developing in the course of ACTH-dependent Cushing's disease (CD).

\section{Case}

A47-year-old woman was admitted to theendocrinology outpatient clinic with weight gain, fatigue and unregulated blood glucose levels. She had a 13-year history of type 2 diabetes mellitus, which was uncontrolled despite basalbolus insulin treatment [hemoglobin A1c (HbA1c): 9\%]. She was examined for CS four years ago. Her basal serum
Address for Correspondence/Yazışma Adresi: Muzaffer illhan

Ümraniye Training and Research Hospital, Clinic of Endocrinology and Metabolism Diseases, istanbul, Turkey E-mail: muzoilhan@yahoo.com

Received/Geliş Tarihi: 21 January 2016 Accepted/Kabul Tarihi: 23 March 2016

This study was presented as a poster on 21-25 May 2014 in the Congress of Endocrine and Metabolism Diseases of Turkey.
${ }^{\circ}$ Copyright 2017 by The Medical Bulletin of Haseki Training and Research Hospital The Medical Bulletin of Haseki published by Galenos Yayınevi. ${ }^{\bullet}$ Telif Hakkı 2017 Haseki Eğitim ve Araştırma Hastanesi Haseki Tıp Bülteni, Galenos Yayınevi tarafından basıımıştır. 
cortisol and ACTH levels were $10.74 \mathrm{ug} / \mathrm{dL}$ (6.7-22.6) and $65.3 \mathrm{pg} / \mathrm{mL}(7.2-63.3 \mathrm{pg} / \mathrm{mL})$, respectively. The serum cortisol level after $1 \mathrm{mg}$ dexamethasone suppression test was $6.57 \mathrm{ug} / \mathrm{dL}$ and it was $5.15 \mathrm{ug} / \mathrm{dL}$ after $8-\mathrm{mg}$ dexamethasone suppression test. Pituitary magnetic resonance imaging (MRI) showed a $5 \times 5 \mathrm{~mm}$ adenoma on the right hemisphere of the hypophysis and her abdominal MRI showed an adrenal adenoma measuring $1 \mathrm{~cm}$ in diameter on the left side. Bilateral inferior petrosal sinus sampling (BIPSS) was performed for differential diagnosis. Right inferior petrosal sinus basal central/peripheral ratio was 12:1 and corticotrophin-releasing hormone (CRH)stimulated ratio was $8: 1$, which were compatible with CD (Table). The pituitary adenoma was removed with transnasal transsphenoidal surgery. Pathology of the mass was compatible with adenohypophysis tissue showing diffuse fibrosis and positivity with prolactin, growth hormone, follicle-stimulating hormone, thyroid stimulating hormone and ACTH. However, it was consistent neither with microadenoma nor with hyperplasia.

Three months after the operation, her serum cortisol level after 1-mg dexamethasone suppression test was $7.5 \mathrm{ug} / \mathrm{dL}$. Basal serum cortisol level was $12.3 \mathrm{ug} / \mathrm{dL}$ and after 8-mg dexamethasone, it was $7.7 \mathrm{ug} / \mathrm{dL}$. BIPSS was repeated to confirm the diagnosis of $C D$ and on the right inferior petrosal sinus, basal central/peripheral ratio was $<2: 1$, but $C R H$-stimulated ratio was 17:1. BIPSS results showed that right lateralized CD was persisting (Table). Pituitary MRI showed no adenoma and gamma knife radiosurgery was performed.

In the third year of gamma knife radiosurgery, the patient was admitted to our outpatient clinic with weight gain and unregulated blood glucose levels (HbA1c: 11\%). $1 \mathrm{mg}$ and $2 \mathrm{mg}$ dexamethasone suppression tests revealed no suppression and hypercortisolemia were persisting, but ACTH level was suppressed $(4.29 \mathrm{pg} / \mathrm{mL})$ for the first time since she was diagnosed with CD. 8 mg-dexamethasone suppression test showed also no suppression. Abdominal MRI showed $24 \times 18 \times 22 \mathrm{~mm}$ adenoma on the left adrenal gland and there was no hyperplasia on both adrenal glands (Figure 1). The patient was diagnosed with adrenal

\begin{tabular}{|l|l|l|l|l|}
\hline Table. Bilateral inferior petrosal sinus sampling results \\
\hline \multirow{4}{*}{} & \multicolumn{4}{|c|}{ ACTH (pg/mL) } \\
\cline { 2 - 5 } & $\begin{array}{c}\text { Before pituitary } \\
\text { surgery }\end{array}$ & $\begin{array}{c}\text { Before gamma } \\
\text { knife }\end{array}$ \\
\cline { 2 - 5 } & $\begin{array}{l}\text { Before } \\
\text { CRH }\end{array}$ & $\begin{array}{l}\text { After } \\
\text { CRH }\end{array}$ & $\begin{array}{l}\text { Before } \\
\text { CRH }\end{array}$ & $\begin{array}{l}\text { After } \\
\text { CRH }\end{array}$ \\
\hline Right petrosal sinus & 1250 & 1250 & 49 & 1250 \\
\hline Left petrosal sinus & 87 & 16 & 52 & 98 \\
\hline Peripheral & 109 & 152 & 52 & 103 \\
\hline ACTH: Adrenocorticotropic hormone, CRH: Corticotropin releasing hormone \\
\hline
\end{tabular}

CS and left adrenalectomy was performed. Histological investigation revealed an adrenal adenoma without any hyperplasia or atrophy in the surrounding cortex (Figure 2, Figure 3). One month after adrenalectomy, her serum cortisol level was suppressed with $1 \mathrm{mg}$ dexamethasone $(0.55 \mathrm{ug} / \mathrm{dL})$ and the patient was considered cured. After three months, she had a $10 \mathrm{~kg}$ weight loss; her $\mathrm{HbA} 1 \mathrm{c}$ level decreased from $11 \%$ to $9 \%$ and, her cortisol level was suppressed with 1 -mg dexamethasone $(0.73 \mathrm{ug} / \mathrm{dL})$.

\section{Discussion}

We presented an unusual Cushing case that pituitary and adrenal CS were coexisting in the same patient. The combined findings of the right-sided pituitary lesion on MRI and demonstration of the central source of ACTH secretion by BIPSS were considered to be sufficient evidence for $C D$ and she was treated with pituitary surgery. After surgery, because of persisting hypercortisolemia and BIPSS results indicating pituitary source, gamma knife radiosurgery was performed. Three years after gamma knife radiosurgery, hypercortisolemia was still persisting and differential

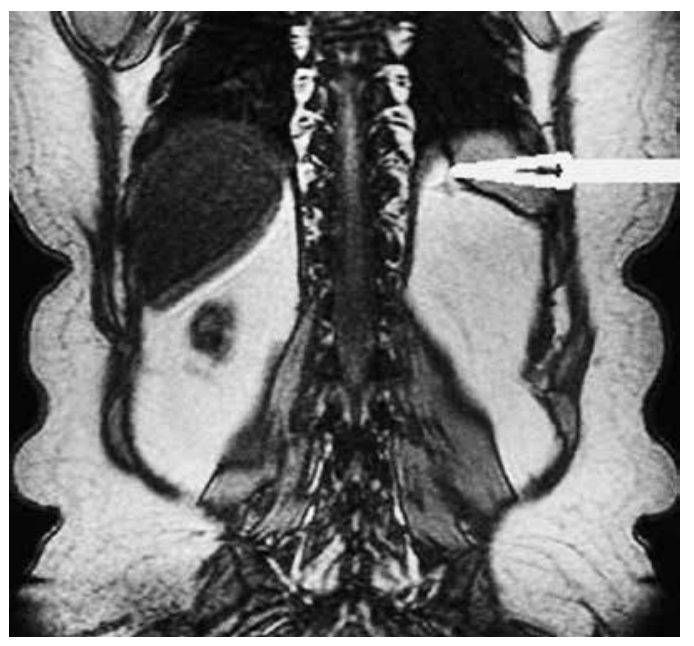

Figure 1. $24^{\star} 18^{\star} 22 \mathrm{~mm}$ large adrenal adenoma (left side)

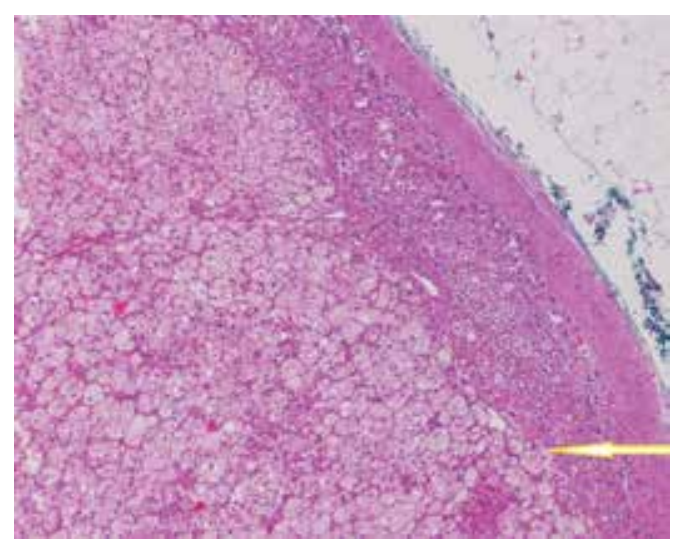

Figure 2. Adrenal adenoma (left side) and residual adrenal tissue (right side) 
diagnoses were persistent $C D$, macronodular adrenal hyperplasia and adrenal adenoma. Diagnostic work up with suppressed ACTH levels indicated that the left adrenal adenoma became functional. The observed response to $1 \mathrm{mg}$ dexamethasone suppression test after left adrenalectomy also pointed towards unilateral adrenal autonomous hypersecretion of cortisol.

Despite bilateral adrenocortical hyperplasia in CD is a well-defined entity and can be found in $70-80 \%$ of patients with $C D$, autonomic transformation of adrenal glands due to longstanding ACTH hypersecretion is still a matter of debate $(6,7)$. Although coincidence of nonfunctioning tumors in adrenal or pituitary is a common finding in diagnostic steps of CS, coexistence of both functional pituitary and adrenal lesions in same patient has been reported in only a few cases. Timmers et al. (6) reported a case of $C D$ which reoccurred after ten months of transsphenoidal surgery because of autonomous cortisol secretion of adrenal macronodule. In that case, coexistent macro and microhyperplasia in the resected adrenal gland suggested that macronodular hyperplasia could be the later stage of micronodular hyperplasia and indicated the possible transition of pituitary-dependent to adrenal-dependent CS. Hermus et al. (7) reported that removal of ACTH stain-positive pituitary adenoma and subsequent resection of the left adrenal gland with 3.5 $\mathrm{cm}$ adrenal nodule which was surrounded by an atrophic cortex did not cure hypercortisolism in a patient with CS. Contralateral adrenalectomy which histologically showed micronodular hyperplasia suggested that ACTHdependent CS might lead to adrenal-dependent CS. In our case, when the shift of ACTH dependency to ACTH independency of recurrent hypercortisolism was detected at the third year of gamma knife surgery, abdomen MRI showed left adrenal adenoma without any hyperplasia. Histological investigation revealed an adrenal adenoma without any hyperplasia or atrophy in the surrounding cortex which was distinct from other two cases. To our

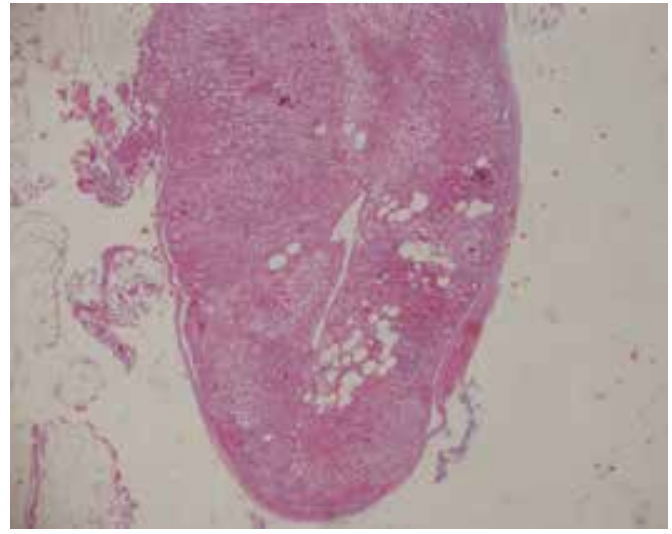

Figure 3. Normal adrenal tissue without hyperplasia or atrophy knowledge, this is the first case of coexistence of functional pituitary and adrenal adenoma.

In conclusion, along with the rare possibility of this coexistence, evolving of nonfunctional adrenal adenoma to cortisol hypersecreting adenoma in the course of $C D$ suggests that longstanding ACTH hypersecretion can play a role in functional transition of adrenal adenomas, although underlying mechanisms are still not clarified. An accurate endocrine evaluation is always mandatory and CS should be considered carefully in follow-up, as well as every steps of diagnosis, to provide successful and appreciate management.

\section{Ethics}

Informed Consent: It was taken.

Peer-review: Externally peer-reviewed.

\section{Authorship Contributions}

Surgical and Medical Practices: Özcan Karaman, Muzaffer Illhan. Concept: Muzaffer illhan, Ertuğrul Taşan, Nur Büyükpınarbaşılı. Design: Muzaffer illhan, Ertuğrul Taşan. Analysis or Interpretation: İrem Yasin Çetin, Jamshid Hamdard, Nur Büyükpınarbaşılı. Literature Search: İrem Yasin Çetin, Jamshid Hamdard. Writing: Muzaffer Illhan, Irem Yasin Çetin.

Conflict of Interest: No conflict of interest was declared by the authors.

Financial Disclosure: The authors declared that this study received no financial support.

\section{References}

1. Sharma ST, Nieman LK. Cushing's syndrome: all variants, detection, and treatment. Endocrinol Metab Clinics North Am 2011;40:379-91.

2. Etxabe J, Vazquez JA. Morbidity and mortality in Cushing's disease: an epidemiological approach. Clin Endocrinol (oxf) 1994;40:479-84.

3. Lahera Vargas M, da Costa CV. [Prevalence, etiology and clinical findings of Cushing's syndrome]. Endocrinol Nutr 2009;56:32-9.

4. Newell-Price J, Trainer P, Besser M, Grossman A. The diagnosis and differential diagnosis of Cushing's syndrome and pseudoCushing's states. Endocr Rev 1998;19:647-72.

5. Newell-Price J, Bertagna $X$, Grossman AB, Nieman LK. Cushing's syndrome. Lancet 2006;367:1605-17.

6. Timmers HJ, van Ginneken EM, Wesseling P, Sweep CG, Hermus AR. A patient with recurrent hypercortisolism after removal of an ACTH-secreting pituitary adenoma due to an adrenal macronodule. J Endocrinol Invest 2006;29:934-9.

7. Hermus $A R$, Pieters GF, Smals $A G$, et al. Transition from pituitary-dependent to adrenal-dependent Cushing's syndrome. N Engl J Med 1988;318:966-70. 